\title{
Gastric Adenocarcinoma Deposits Presenting as Multiple Cutaneous Nodules: A Case Report with Review of Literature
}

\section{Multipl Kutanöz Nodüllerle Kendini Gösteren Mide Adenokarsinomu: Olgu Sunumu}

\author{
Aparna NARASIMHA, Harendra KUMAR \\ Department of Pathology, Sri Devaraj Urs Medical College, Sri Devaraj Urs Academy of Higher Education and Research, Kolar, KARNATAKA, INDIA
}

\begin{abstract}
Metastases to the skin from internal tumors are uncommon, yet they may be the first presentation of such malignancies. They usually arise from the breast, lung and large bowel. Cutaneous metastases from gastric adenocarcinoma are extremely rare. We report a case of gastric adenocarcinoma that at presentation had multiple clinically benign looking skin nodules. Fine needle aspiration cytology of the cutaneous nodule revealed metastatic deposits. The current literature on cutaneous metastases of gastric carcinoma is reviewed in this case report.
\end{abstract}

Key Words: Skin, Metastasis, Gastric cancer, Fine-needle, Aspiration cytology

\begin{abstract}
ÖZ
Organlardan deriye metastaz nadirdir ancak malignitenin ilk çıkış şekli olabilir. Genellikle meme, akciğer ve kalın barsak kökenlidir. Mide adenokarsinomunun deri metastazı ise çok ender görülür. Burada, tanı esnasında çok sayıda deri metastazı olan bir mide adenokarsinomu olgusu sunulmaktadır. Deri nodülünün ince iğne aspirasyon sitolojisi metastazı göstermiştir. Bu olgu sunumunda mide kanserlerinin deri metastazlarına ait literatür derlenmektedir.
\end{abstract}

Anahtar Sözcükler: Deri, Metastaz, Mide kanseri, İnce iğne, Aspirasyon biyopsi

\section{INTRODUCTION}

Cutaneous metastases may occur as the initial manifestation of internal malignancy or late in the course of the disease. Furthermore, they can be the first sign of disseminated neoplasm or an important presenting feature of recurrence after successful therapy. The course of cutaneous metastases may also be used as a reflection of the behavior of the internal lesions, in particular their response to systemic chemotherapy. Presence of cutaneous metastases may progress the stage of an internal malignancy and hence affect its prognosis. In general, cutaneous metastases are associated with advanced systemic cancers and the expected survival is less than one year $(1,2)$.

This case is reported for its rarity of presentation and to highlight the importance of cutaneous metastases as a poor prognostic sign for the patient.

\section{CASE REPORT}

A 66-year-old woman came with a history of fever and generalized weakness since 1 month. The patient gave a history of having undergone surgery for gastric ulcers 17 years back. The histopathology report was unavailable.

Examination revealed enlarged cervical and supraclavicular lymph nodes. Multiple subcutaneous nodules (around four) were seen over the abdomen largest measuring $2 \times 2$ $\mathrm{cm}$, firm in consistency and freely mobile.

A hard mass was palpable in the epigastric region, measuring about $8 \times 5 \mathrm{~cm}$, fixed to the underlying structures. The patient also had pleural effusion and ascites.

Computed Tomography (CT) scan of the abdomen revealed a soft tissue mass lesion in the retropancreatic, periportal, pre-aortic and bilateral para-iliac regions along with multiple mesenteric lymphadenopathies, minimal left sided hydronephrosis, bilateral pleural effusion and 
moderate ascites. A provisional diagnosis of disseminated malignancy was given.

Ultrasound guided fine needle aspiration cytology (FNAC) of the retroperitoneal mass along with FNAC of cervical, supraclavicular lymph nodes and cutaneous nodules were done.

Cytology findings: Fine needle aspiration smears showed pleomorphic round to oval cells arranged in groups, glandular and papillary patterns (Figure 1) with vesicular nucleus showing prominent nucleoli and scanty eosinophilic cytoplasm (Figure 2). A few signet ring cells were also observed. A possibility of gastric/pancreatic adenocarcinoma with lymph node and cutaneous metastases was suggested.

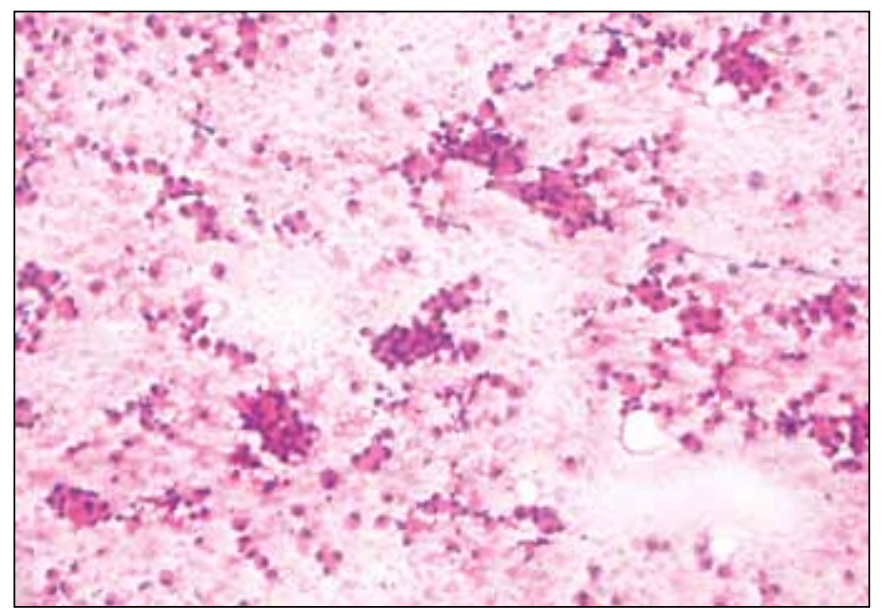

Figure 1: Microphotograph of fine needle aspiration smears showing tumor cells arranged in groups, glandular and papillary patterns (H\&E, x100).

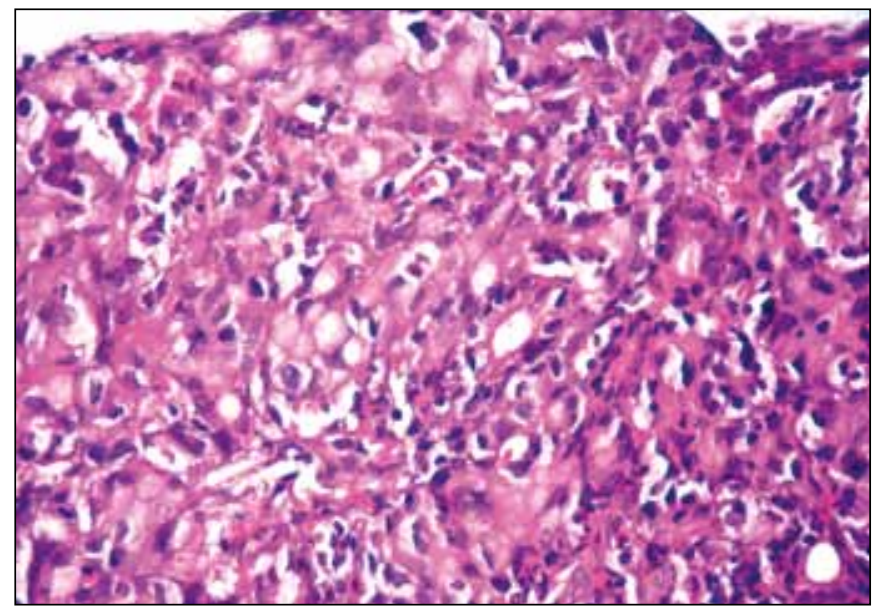

Figure 3: Microphotograph of biopsy showing fragments of gastric mucosa with signet ring cells seen infiltrating the stroma (H\&E, x400).
Upper Gastrointestinal (GI) endoscopy showed a large stomal ulcer on the body of stomach. Biopsy sent revealed fragments of gastric mucosa showing tumor cells arranged in groups (Figure 3). Cells were pleomorphic with round to oval nucleus having fine chromatin and moderate amount of eosinophilic cytoplasm. Signet ring cells were also seen infiltrating the stroma. Mucin was demonstrated by mucicarmine stain (Figure 4). The above features were compatible with mucin secreting gastric adenocarcinoma with cutaneous metastases. Subsequently the patient died before the surgery could be performed.

\section{DISCUSSION}

Skin or cutaneous metastases refer to growth of cancer cells in the skin originating from an internal cancer. In most cases, cutaneous metastases develop after the initial

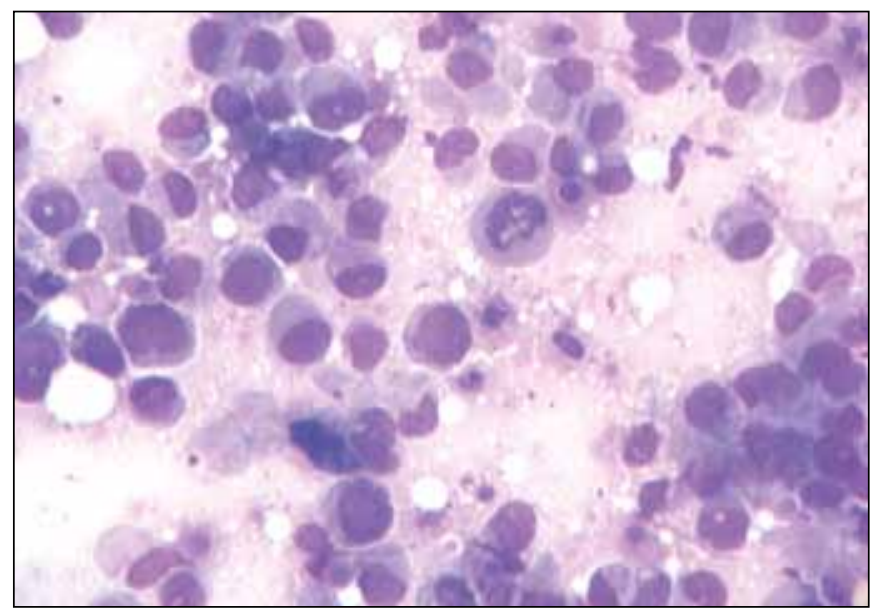

Figure 2: Microphotograph of fine needle aspiration smears showing pleomorphic round to oval cells (MGG, x1000).

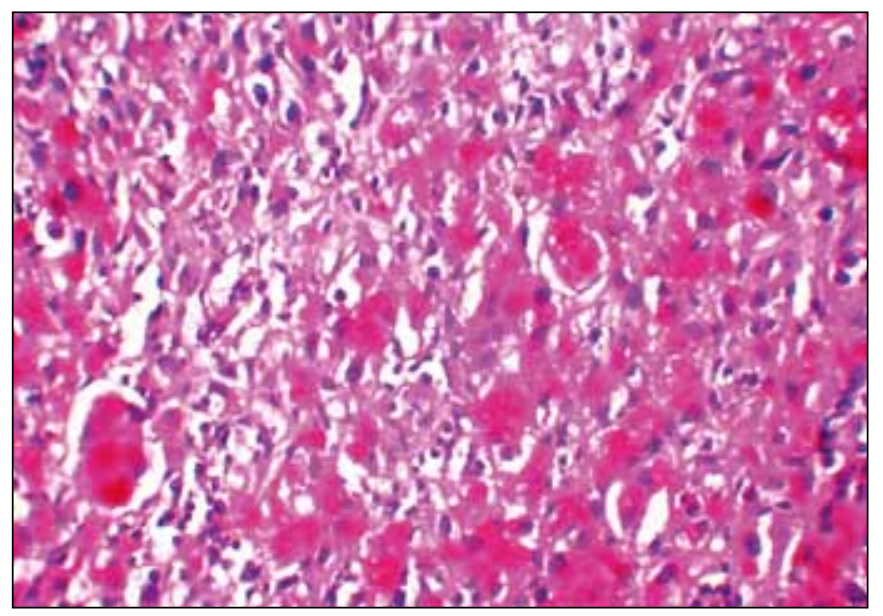

Figure 4: Microphotograph of tumor cells showing mucin (Mucicarmine, x1000). 
diagnosis of the primary internal malignancy such as breast or lung cancer and late in the course of the disease (1). But, in our case the primary presentation of the patient was with multiple subcutaneous nodules.

The incidence of cutaneous metastases from neoplasms of internal organs as estimated from autopsy studies varies from 0.6 to $9 \%$ of all cases of malignant disease (3). Cutaneous metastases occur most frequently among women with breast cancer (18.6\%-50\%) and men with bronchogenic carcinoma (3\%-7.5\%) (1).

Carcinoma of the stomach presenting as multiple cutaneous metastases is rare (4). It can present as a nodule, cellulitislike skin lesion or as an erysipelas-like picture (5). It is even more uncommon and unusual to have a patient with gastric carcinoma whose mode of presentation is that of 'skin nodule' (6).

Common sources of cutaneous metastases in women are the breast (69\%), the colon (9\%), melanoma (5\%), the ovaries (4\%), and the lungs (4\%). In men, they are the lungs $(24 \%)$, the colon $(19 \%)$, melanoma (13\%), and the oral cavity (12\%) (7).

Vachhani etal (8)have reported a rare case of adenocarcinoma of lung presenting as malignant pericardial effusion and cutaneous metastasis as an initial presentation (8). A rare case of penile metastasis of urothelial carcinoma diagnosed by fine needle aspiration cytology has been reported by Santos et al (9).

The most common presentation of cutaneous metastases is nodules. The nodules are often non-painful, round or oval, firm, mobile and rubbery in consistency. The nodules are usually flesh colored to brown or blue-black (7).

FNAC followed by skin biopsy helps in confirming a diagnosis of tumor. Immunohistochemical marker studies and ultrastructural examination may help to delineate the tissue of origin. Imaging studies like Magnetic Resonance Imaging, CT and ultrasonography may be employed in select cases if the biopsy sample is impartial or if performing a biopsy is dangerous because of proximity to vital organs (7).

The skin metastases may be isolated or associated with metastasis at multiple sites. Cancer metastasis to the skin most commonly occurs as indolent cutaneous nodules that tend to be localized at the head, neck, chest and abdomen and represent a serious prognostic sign particularly in patients with cancers of lung, ovary, upper respiratory tract or upper digestive tract $(3,4)$.

Gastric carcinomas usually metastasize to the liver, peritoneal cavity and regional lymph nodes more often than to the skin and when cutaneous metastases occur they usually arise in the vicinity of the primary tumor (e.g the abdominal wall). Cutaneous metastases from adenocarcinomas of the stomach may be solitary or multiple and has appeared on the head, eyebrow, neck, axillae, chest, lip, fingertips, shoulders, arms, umbilical region (4). GI cancers (usually colon and gastric carcinomas) often metastasize to the abdomen and the pelvis. GI cancers may spread along the urachus and produce nodules at umbilicus. The presentation of nodules at the umbilicus has been referred to as a "sister Mary Joseph nodule" (7).

Tumor cells metastasize to the skin through several routes, namely direct invasion from underlying structures, extension and embolization through lymphatics and blood vessels, spread along ligaments of embryonic origin and accidental implantation during surgery. Generally cutaneous metastases are associated with advanced systemic disease and expected survival is less than one year $(1,2)$. Nodular carcinoma, inflammatory or erysipeloides carcinoma, telangiectatic and "en cuirasse" are the typical clinical manifestations of the lymphatic dissemination of breast cancers to skin (10).

In most cases, cutaneous metastases develop after the initial diagnosis of primary malignancy. In a very small percentage of patients, metastases may be discovered at the same time or prior to the diagnosis of a primary tumor (e.g., lung and renal cell carcinoma) (7). A study by Hori et al showed that the average interval between the detection of the primary cancer and the appearance of the skin lesion was 20 months (11). Prognosis is usually poor owing to the presence of widespread metastases (11).

Our case was also unique in that the patient presented with subcutaneous nodules, had a rapid downhill course before the actual treatment plan could be executed, and the patient expired within a very short duration.

Cutaneous metastases are infrequent manifestations of solid tumors. Though they usually appear late in the course of the disease, they may constitute the presenting sign which was observed in our case.

Hence it is important to recognize them since they may be the first evidence of a neoplasm or a sign of tumor progression or recurrence.

\section{REFERENCES}

1. Brownstein MH, Helwig EB: Patterns of cutaneous metastasis. Arch Dermatol 1972, 105:862-868

2. Arun J, Prasad SS: Cutaneous metastatic adenocarcinoma. Indian J Dermatol Venereal Leprol 2001, 67:207-208

3. Lookingbill DP, Spangler N, Helm KF: Cutaneous metastases in patients with metastatic carcinoma: A retrospective study of 4,020 patients. J Am Acad Dermatol 1993, 29:228-236 
4. Navarro V, Ramon D, Calduch L, Llombart B, Monteagudo C, Jorda E: Cutaneous metastasis of gastric adenocarcinoma: an unusual clinical presentation. Eur J Dermatol 2002, 12:85-87

5. Foo KF, Tao M, Tan EH: Gastric carcinoma presenting with cellulites- like cutaneous metastasis. Singapore Med J 2002, 43:37-38

6. Ng Ky, Ng HS, Ong YY, Ong BH, Giam YC: Cutaneous metastases - an uncommon and unusual mode of presentation of gastric carcinoma. Singapore Med J 1989, 30:97-101

7. Thomas N, Helm: Dermatologic manifestations of metastatic carcinoma of the skin. [cited March 2 2010]. Available from: http:// emedicine.medscape.com/article/1101058-overview\#showall
8. Vachhani JH, Jessalpara K, Goswami B, Santwani PM: Malignant pericardial effusion and cutaneous metastasis - an initial presentation of adenocarcinoma of lung. J Cytol 2007, 24:199-200

9. Santos Gda C, Alvarenga ML, Borlot VF, Moutinho MA, deFranco MF: Penile metastasis of urothelial carcinoma diagnosed by fine-needle aspiration. Cytojournal 2009, 6:10

10. Schwartz RA: Cutaneous metastatic disease. J Am Acad Dermatol 1995, 33:161-182

11. Hori M, Yoshida H: Statistical study of metastatic skin cancers - interrelation of the origin of primary tumor, metastatic skin lesions, prognosis and histopathology. Gan To Kagaku Ryoho 1988, 15:1576-1580 